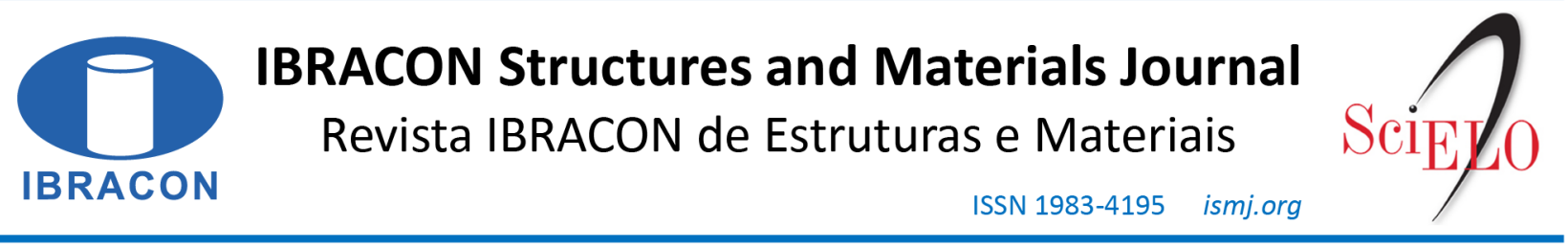

ORIGINAL ARTICLE

\title{
Rice husk ash as supplementary cementing material to inhibit the alkali-silica reaction in mortars
}

\section{Uso da cinza de casca de arroz como adição mineral para inibir a reação álcali- sílica em argamassas}

\author{
Eloise Aparecida Langaro ${ }^{\mathrm{a}}$ (D) \\ Cleberson Adorno dos Santos ${ }^{\mathrm{a}}$ \\ Marcelo Henrique Farias de Medeiros ${ }^{\mathrm{a}}$ (i) \\ Diego Souza de Jesus ${ }^{\mathrm{b}}$ (1) \\ Eduardo Pereira ${ }^{\mathrm{c}}$
}

\author{
${ }^{a}$ Universidade Federal do Paraná - UFPR, Programa de Pós-graduação em Engenharia Civil, Curitiba, PR, Brasil \\ ${ }^{b}$ University of Ottawa, Department of Civil Engineering, Ottawa, Canada

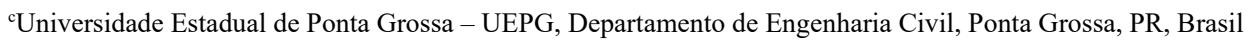

Received 14 January 2020 Accepted 09 November 2020

\begin{abstract}
Alkali-silica reaction (ASR) is one of the most harmful distress mechanisms that affects the durability of concrete worldwide. Yet, it has been found that ASR-induced expansion and distress may be prevented by the appropriate use of supplementary cementing materials (SCMs). Recent studies suggest that rice husk ash (RHA), a by-product of the rice production, may present promising performances as a pozzolanic material and to enhance the durability of blended mixtures. There are many controversial studies regarding the use of RHA and how its properties directly affect the performance and durability of concretes and mortars. The present study aims to evaluate the influence of the RHA on ASR through the accelerated mortar bar test (AMBT), X-Rays Diffraction (XRD), Thermogravimetric Analysis (TG), Mercury Intrusion Porosimetry (MIP) and Scanning Electron Microscopy (SEM). To validate the obtained data, the results were compared with mortars made of a well-known SCM (silica fume) which has distinguished behaviour against ASR. The results indicate that, besides the silica fume mortars have showed better results, the use of RHA suggests promising results to mitigate the ASR, yet, further analysis on concrete prims test should be carried out to fully validate the use of RHA to enhance the durability of the concrete. The RHA finesses and its particle size were the most important properties in the SCM performance.
\end{abstract}

Keywords: rice husk ash, pozzolanicity, alkali-silica reaction, particle size distribution.

Resumo: A reação álcali-sílica (RAS) é um dos mais nocivos mecanismos que afetam a durabilidade do concreto em todo o mundo. No entanto, já foi verificado que a expansão e a deterioração do concreto, devido a RAS, podem ser evitadas pelo uso de materiais apropriados, como adições minerais. Estudos recentes sugerem que a cinza da casca de arroz (CCA), um subproduto da produção de arroz, pode apresentar desempenho promissor como material pozolânico para aumentar a durabilidade de misturas com cimento Portland. Existem muitos estudos controversos a respeito do uso da CCA e como suas propriedades afetam diretamente o desempenho e a durabilidade de concretos e argamassas. O presente estudo teve como objetivo avaliar a influência da CCA na RAS através do teste acelerado de barras de argamassa (AMBT), Difração de Raios-X (DRX), Análise Termogravimétrica (TG), Porosimetria por Intrusão de Mercúrio (MIP) e Microscopia Eletrônica de Varredura (MEV). Para validar os dados obtidos, os resultados foram comparados com argamassas confeccionadas com uma reconhecida adição mineral (sílica ativa), a qual possui notável comportamento frente a RAS. Os resultados indicam que, além das argamassas de sílica ativa apresentarem melhores resultados, o uso de CCA pode sugerir resultados promissores para mitigar o RAS. Porém, análises adicionais a partir do ensaio de primas de concreto devem ser realizados para validar plenamente o uso desta cinza para aumentar a durabilidade do concreto. A finura

Corresponding author: Eloise Aparecida Langaro. E-mail: elolangaro@hotmail.com

Financial support: Coordenação de Aperfeiçoamento de Pessoal de Nível Superior - CAPES.

Conflict of interest: Nothing to declare.

This is an Open Access article distributed under the terms of the Creative Commons Attribution License, which permits unrestricted use, distribution, and reproduction in any medium, provided the original work is properly cited. 
o tamanho das partículas da CCA foram as características que mais tiveram impacto no desempenho da adição mineral.

Palavras-chave: cinza de casca de arroz, pozolanicidade, reação álcali-sílica, distribuição granulométrica.

How to cite: E. A. Langaro, C. A. Santos, M. H. F. Medeiros, D. S. Jesus, and E. Pereira, "Rice husk ash as supplementary cementing material to inhibit the alkali-silica reaction in mortars," Rev. IBRACON Estrut. Mater., vol. 14, no. 4, e14404, 2021, https://doi.org/10.1590/S198341952021000400004

\section{INTRODUCTION}

Concrete is the most common construction material used in critical infrastructure worldwide. Portland cement (PC) is by far the most important ingredient of concrete, being the main responsible for its carbon-footprint and accounting for about $7 \%$ of the annual man-made $\mathrm{CO}_{2}$ emission [1]. Which enhance the technical importance of finding costeffective strategies to reduce the carbon-footprint associated with the production of PC. Moreover, one of the most adopted methods for reducing environmental impact of PC involves the use of supplementary cementing materials (SCMs) in concrete. Yet, major developments need to be constantly addressed in this area, specially aiming to the longterm behaviour of these materials when used in concrete structures.

Alkali-silica reaction (ASR) is one of the most harmful distress mechanisms that affects the durability of concrete worldwide. It is comprised of a chemical reaction between "unstable" silica mineral forms (from fine or coarse aggregates) and alkali hydroxides (e.g. $\mathrm{Na}^{+}, \mathrm{K}^{+}$and $\mathrm{OH}^{-}$) dissolved within the concrete pore solution [2]. It generates a secondary product, the ASR-gel, which has swelling properties and may generate internal stresses and cracking in the concrete [2]-[4]. One may notice, once the reaction takes place, there is any well stablished method or technique to complete stop the reaction; mostly, it's only delay the rate of occurrence [5], which reinforce that preventive measures are, in general, a better solution. For that, an adequate selection of material and well-proportioned concrete are best options. Moreover, it has been found that ASR-induced expansion and distress may be prevented by the appropriate use of supplementary cementing materials (SCMs) [6].

The technical importance binder composition with supplementary cementitious materials (SCMs) derives mainly from three aspects: 1) the reaction is slow, therefore, the release of heat due to the hydration reactions is also slow; 2) the reactions caused by these materials consume calcium hydroxide, rather than producing them, reducing the $\mathrm{pH} ; 3$ ) the interaction between amorphous silica, portlandite and water present in the concrete pores leads to further formation of C-S-H [3], [7]-[9]. The C-S-H formed from pozzolanic reactions has lower $\mathrm{Ca} / \mathrm{Si}$ ratio than the commonly C-S-H; hence, enhancing the capacity of alkali bonding $\left(\mathrm{Na}+\right.$ and $\left.\mathrm{K}^{+}\right)$[9], [10].

Siliceous SCMs, such as Silica Fume (SF) and Rice Husk Ash (RHA), etc. consists nearly exclusively of $\mathrm{SiO}_{2}$ of fine particle size and a relatively high pozzolanic activity. These materials, especially SF, are widely used to improve the compressive strength, abrasion resistance and durability of concrete [11], [12]. Moreover, the use of SF and RHA as part of the binder composition may mitigate or, at least, delay the development of ASR [3], [8]-[10]. Although, the effective performance of the RHA in cementitious materials is in function of several aspects, such as: the amount of silica, amorphous degree (dependent of the process of burning) and the average particle size distribution. De Souza et al. [13] presented an extensive review regarding the obtention of reactive silica from rice husk ash. The fabrication process implies in significant variations in the physical/morphological and chemical properties of the RHA grains; moreover, directly affecting the properties of cementitious materials made with RHA [13]-[17]. The controlled burning process of the RHA controls, besides the crystallinity of the RHA particles, the carbon content attached in the grains [18]-[20]. Moreover, depending of the amount of carbon on composition of RHA, some particle is able to present some hydrophilic behaviour leading to lack of available water for cement hydration reaction increasing rheological properties of the concrete [18]-[21]. Furthermore, also decreasing or slowing down the RHA reactivity with $\mathrm{Ca}(\mathrm{OH})_{2}$ and affecting the amount of entrapped air in the concrete as well [21].

The RHA, a by-product of the rice production, constantly generated concerns regarding its disposal in nature, once currently RHA is used as land-filled disposal. Which enhance the importance of findings to validate its use as an alternative to replace the PC towards a greener and more durable future of the civil industry. Moreover, the present study aims to evaluate the influence of the RHA to suppress ASR in mortar bar specimens. To achieve the main objective, it will be conducted the accelerated mortar bar test (AMBT), X-Rays Diffraction (XRD), Thermogravimetric Analysis (TGA), Mercury Intrusion Porosimetry (MIP) and Scanning Electron Microscopy (SEM) analyses. To validate the obtained data, the results will be compared with mortars made of a well-known SCM (silica fume) which has distinguished behaviour against ASR. 


\section{MATERIALS AND EXPERIMENTAL PROGRAM}

The reactive aggregate selected is from the region of Curitiba, Brazil. The aggregate has known potential ASRreactivity; moreover, the aforementioned aggregate was used in the construction of different dams in Brazil and have been previously reported in research [22]. Furthermore, the mineralogical phases of the material were identified using the technique of X-Ray Diffraction (XRD) with variation range of $2 \theta$ from $5^{\circ}$ to $75^{\circ}$. The aggregate was classified as a granite, according to ASTM C294 [23], and presented peaks of sanidine and albite (Figure 1).

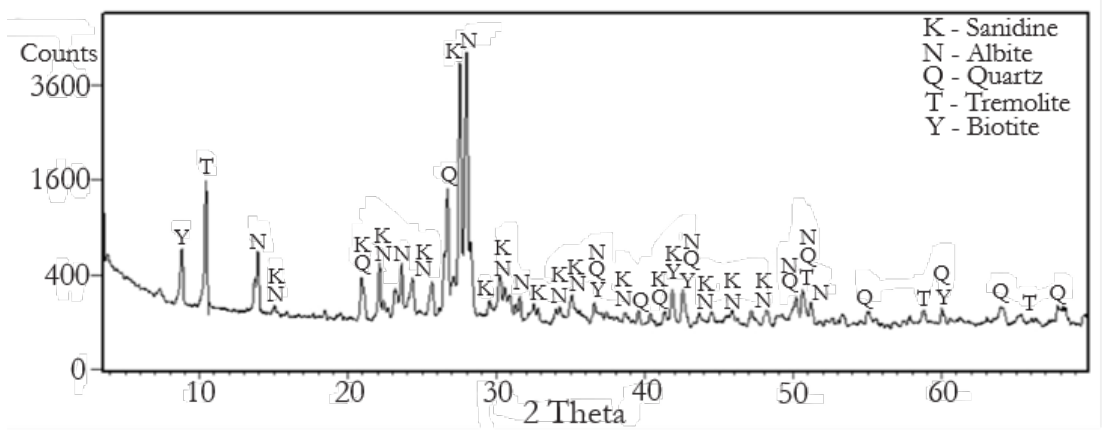

Figure 1. X-ray diffractogram of the reactive aggregate.

The chemical composition (Table 1), obtained through the semi-quantitative spectroscopy analysis (X-Rays Fluorescence-XRF), indicates significant amount of $\mathrm{SiO}_{2}$ (i.e. $63.5 \%$ ) and $8.74 \%$ of $\mathrm{Na}_{2} \mathrm{Oe}_{\mathrm{q}}$. Besides the reactive phases of the aggregate, the amount of alkalis available may be released in the pore solution of the concrete accelerating the development of ASR, specially in the field [24], [25].

Table 1. Chemical composition (oxides \%) of aggregate.

\begin{tabular}{cccccccccc}
\hline & \multicolumn{7}{c}{ Chemical composition (\%) } \\
\cline { 2 - 10 } Aggregate & $\mathbf{C a O}$ & $\mathbf{S i O}_{2}$ & $\mathbf{A l}_{2} \mathbf{O}_{3}$ & $\mathbf{F e}_{2} \mathbf{O}_{3}$ & $\mathbf{K}_{2} \mathbf{O}$ & $\mathbf{N a}_{2} \mathbf{O}$ & $\mathbf{N a}_{2} \mathbf{O}_{\text {eq }}$ & Other oxides \\
\cline { 2 - 11 } & 2.1 & 63.5 & 15.1 & 7.0 & 6.6 & 4.4 & 8.74 & 0.5 \\
\hline
\end{tabular}

Portland cement with high early age strength CPV - ARI (PC), similar to PC type III as per ASTM C150 [26], was used as a control group and replaced partially (10\% by weight) by the rice husk ash and silica fume [10], [18], [27]. Both supplementary cementitious materials are commercial products. The mixtures were proportioned following ASTM C1260 [28] recommendations (i.e. 1:2.25:0.47, cement to fine aggregate to water/binder ratio, by mass).

The particle size distribution (PSD) of the binder materials was obtained by laser diffraction and displayed in Figure 2. Silica fume shows the finest average PSD, D50 equal to $0.12 \mu \mathrm{m}$; which represents particles 52 times smaller than Portland cement (D50 of $6.24 \mu \mathrm{m}$ ). Rice husk ash displayed the highest average PSD among all binder materials with D50 of $7.89 \mu \mathrm{m}$.

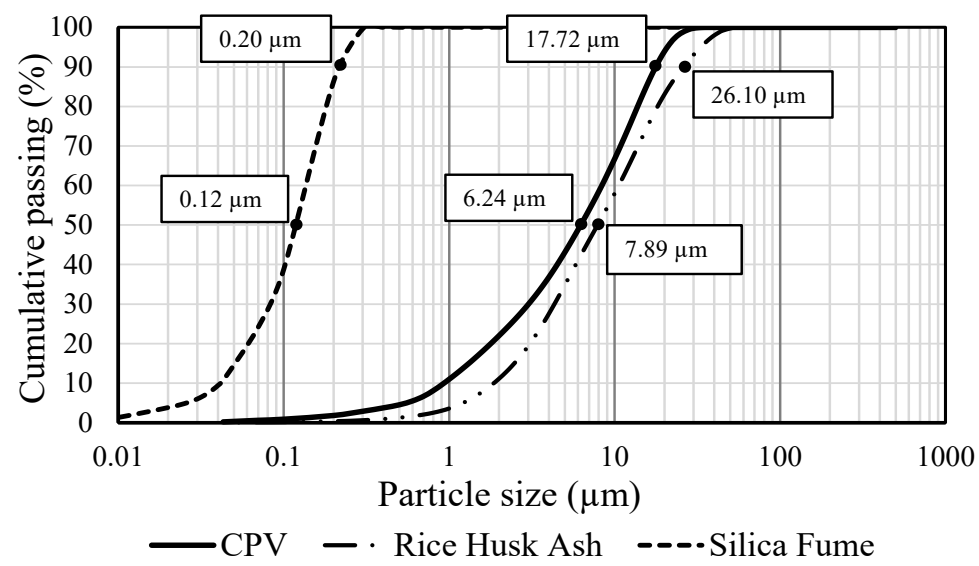

Figure 2. Particle size distribution of materials. 
Table 2 reports the chemical compositions measured by XRF and the results of BET specific surface area, LOI and the specific gravity of the three binder materials. Moreover, the mineralogical composition obtained by the diffractometer RIGAKU Ultima IV X-ray Diffractometer, with range of $2 \theta$ between $5^{\circ}$ and $75^{\circ}$ are presented in Figure 3.

Table 2. Chemical composition (oxides \%) and physical properties of materials.

\begin{tabular}{cccc}
\hline Component & CPV (\%) & Silica fume (\%) & Rice husk ash (\%) \\
\hline $\mathrm{CaO}$ & 59.36 & 0.19 & 0.43 \\
\hline $\mathrm{SiO}_{2}$ & 16.27 & 92.35 & 88.47 \\
$\mathrm{Al}_{2} \mathrm{O}_{3}$ & 5.06 & 2.21 & 2.72 \\
\hline $\mathrm{Fe}_{2} \mathrm{O}_{3}$ & 2.77 & 0.05 & 0.05 \\
\hline $\mathrm{MgO}$ & 4.63 & - & - \\
\hline $\mathrm{SO}_{3}$ & 5.30 & 1.52 & 1.55 \\
\hline $\mathrm{K}_{2} \mathrm{O}$ & 1.06 & 0.94 & 1.46 \\
\hline Other oxides & - & 0.04 & 0.49 \\
\hline $\mathrm{Na}_{2} \mathrm{O}$ eq & 0.697 & 0.619 & 0.961 \\
\hline Free lime* & 1.46 & - & - \\
\hline Insoluble residue & - & - \\
\hline Loss on ignition & 0.67 & 2.70 & 4.84 \\
\hline Specific gravity $\left(\mathrm{g} / \mathrm{cm}^{3}\right)$ & 3.43 & 2.12 & 2.18 \\
\hline
\end{tabular}

* Data provided by the manufacturer

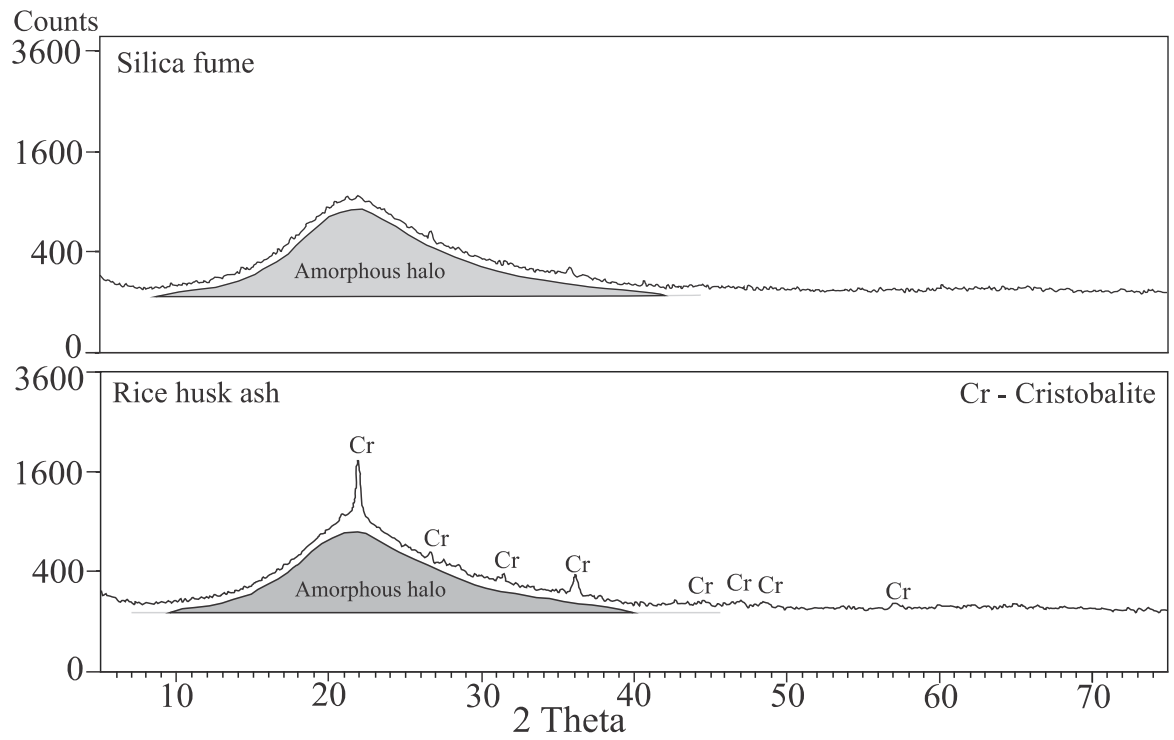

Figure 3. X-ray diffractograms of the silica fume and rice husk ash.

Firstly, the chemical composition (Table 2) indicates that both $\mathrm{SCMs}$ have significantly higher amount of $\mathrm{SiO}_{2}$ than PC; which, SF has the highest value (92.35\%), whereas RHA has $88.47 \%$. Moreover, RHA indicates higher content of LOI and potassium (K); thus, LOI and K may negatively contribute to development of ASR. However, rice husk ash meets the requirements of ASTM C618 [29] with the limit of the specification LOI (6\%) for ashes used in concrete. This material was obtained from the controlled combustion process by fluidized bed of rice husk ash and, thus, despite the temperature control, it is usual a small amount of carbon on its composition. Processes without temperature control led to higher amounts of carbon [30]. 
On the other hand, the diffractogram of RHA indicates that the material is composed basically by amorphous phases (indicated by the amorphous halo) and it has only a small crystal fraction organized as cristobalite. The silica fume did not exhibit peak in the diffractogram, presenting only a characteristic halo from an essentially amorphous microstructure, which may indicate higher pozzolanic reactivity. Moreover, to further understand the pozzolanic reactivity of the SCMs, modified Chapelle's test method was carried out as per NBR 15895 [31]. The obtained data suggests consumption of 1336 and $1542 \mathrm{mg}$ of $\mathrm{Ca}(\mathrm{OH})_{2} / \mathrm{g}$ of pozzolana for RHA and for SF, respectively. Indicating that both materials can be classified as highly reactive SCMs or super pozzolans.

\subsection{Methods to evaluate ASR development}

The efficiency of the SCMs in suppress ASR development was evaluated through the accelerated mortar bar test (AMBT) as per ASTM C1260 [28] and ASTM C1567 [32] on mortars was analyzed in general by two main groups samples. The mortars bars were designed as previously mentioned. After casting and moulding, all bars were subject to $24 \mathrm{~h}$ in the mould in moist cabinet; followed by placing the samples on deionized water at $80 \pm 2^{\circ} \mathrm{C}$ during the next 24 hours. Afterwards, the samples had their initial lengths measured and then, placed in a solution of sodium hydroxide $(\mathrm{NaOH} 1 \mathrm{~N})$ at $80 \pm 2^{\circ} \mathrm{C}$ during a period of 32 days. Moreover, the expansion measured was validated through statistical analysis, Variance Analysis (ANOVA) and Tukey's Test during the two main ages of evaluation (14 and 28 within the 32 days). One may notice that the AMBT was chosen once it allows faster and reliable answers to initially characterize binder mixtures and reactivity of aggregates; yet, concrete prism tests are more indicated to validate the effectiveness of SCMs in mitigate ASR, but the full procedure for CPT normally takes 2 years of development [3]. Which was a limiting factor in this research.

Additionally to AMBT, the well-known X-Ray diffraction (XRD), thermogravimetric analysis (TGA/DTG), mercury intrusion porosimetry (MIP) and scanning electron microscopy (SEM) test methods were also performed in the ASR-affected samples to further understand its development. For the XRD it was used was a diffractometer RIGAKU model Ultima IV with an X-ray tube with the copper anode, $40 \mathrm{kV} / 30 \mathrm{~mA}$, and a divergence slit of $1^{\circ}$. The

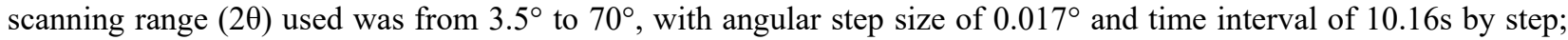
while the TGA analysis was performed in a TA Instruments SDT 2960, in dynamic nitrogen atmosphere $\left(\mathrm{N}_{2}\right)$ and flow rate of $100 \mathrm{~mL} / \mathrm{min}$ with heating rate of $10^{\circ} \mathrm{C} / \mathrm{min}$, applied until the temperature of $1200^{\circ} \mathrm{C}$. Besides that, SEM-EDS were performed in a FEG SEM Tescan, Mira 3 and analytical micro-probe of X-Rays Oxford X-Max 50 (EDX). The sample preparation consisted in a vacuum and metallization with gold. Finally, the mercury intrusion porosimetry the pressures applied were initial of $1.5 \mathrm{psi}$ and final of $30 \mathrm{psi}$.

\section{RESULTS AND DISCUSSIONS}

\subsection{Accelerated Mortar Bar Test (AMBT)}

In this section, ASR expansion kinetics and amplitude results are presented for all 3 mortar bar mixtures. Figure 4 displays the results obtained through the Accelerated Mortar Bar Test (AMBT). The results indicate that, indeed, the finely crushed granite aggregate has potential reactivity for ASR development since the Control mortar mixture displayed expansion amplitudes in between $0.10 \%$ and $0.20 \%$ at 14 and 28 days. Moreover, this result is consistent with results found in the literature [22], in which is discussed the use of the granite aggregate in a Dam construction in Brazil that showed signal of ASR development.

The use both SCMs (for PC's replacement level of 10\%) changed the ASR kinetics and expansion amplitudes. Mortar mixtures made of RHA showed at 14 days results slightly under the limit of $0.10 \%$; yet, at 28 days this mixture developed $0.16 \%$ of expansion which classifies it as a potential mixture to develop ASR. Despite this behaviour, it worth noting that the use of RHA mitigate the reaction compared with the control group (as indicated through the statistical treatment displayed in Figure 5). On the other hand, replacing $10 \%$ of PC by SF, one may notice that granite reactivity was mitigated down to a non-reactive behaviour as per ASTM C 1260. 


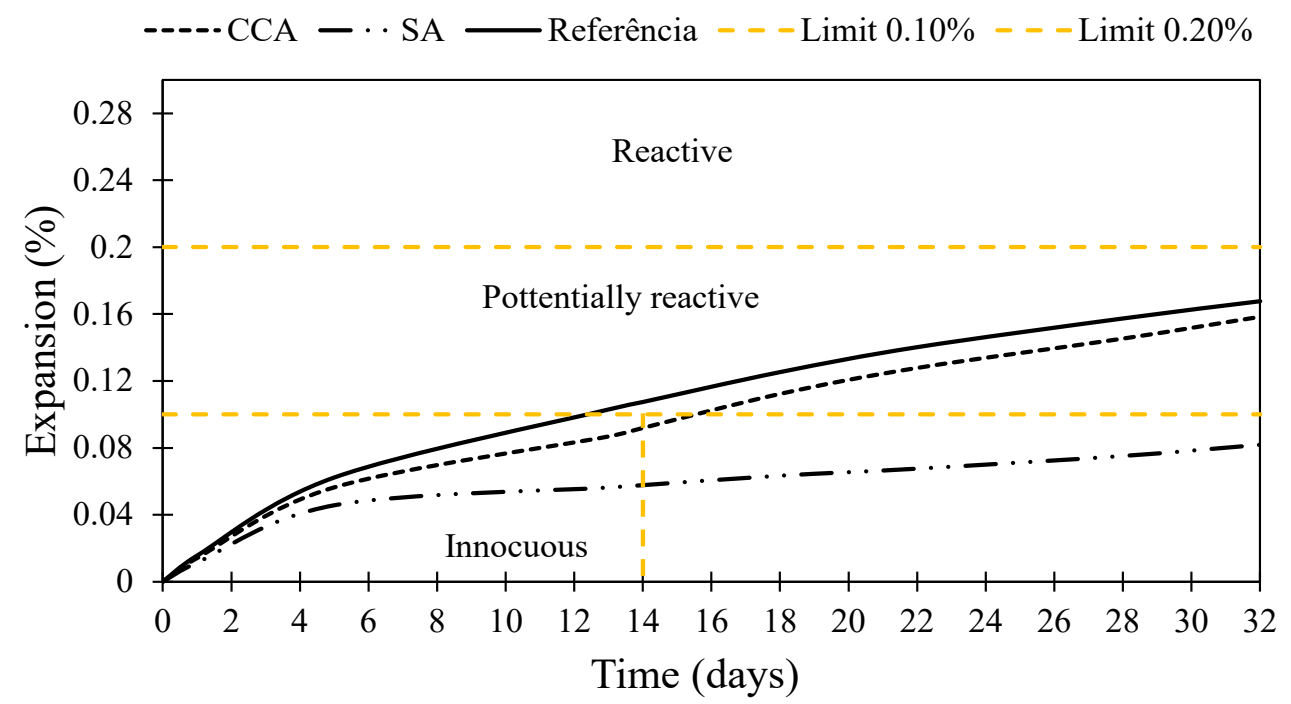

Figure 4. Evolution of the expansion of the mortar bars (AMBT) with 100\% cement (Control) compared with $10 \%$ replacement of SCM (RHA e SF).
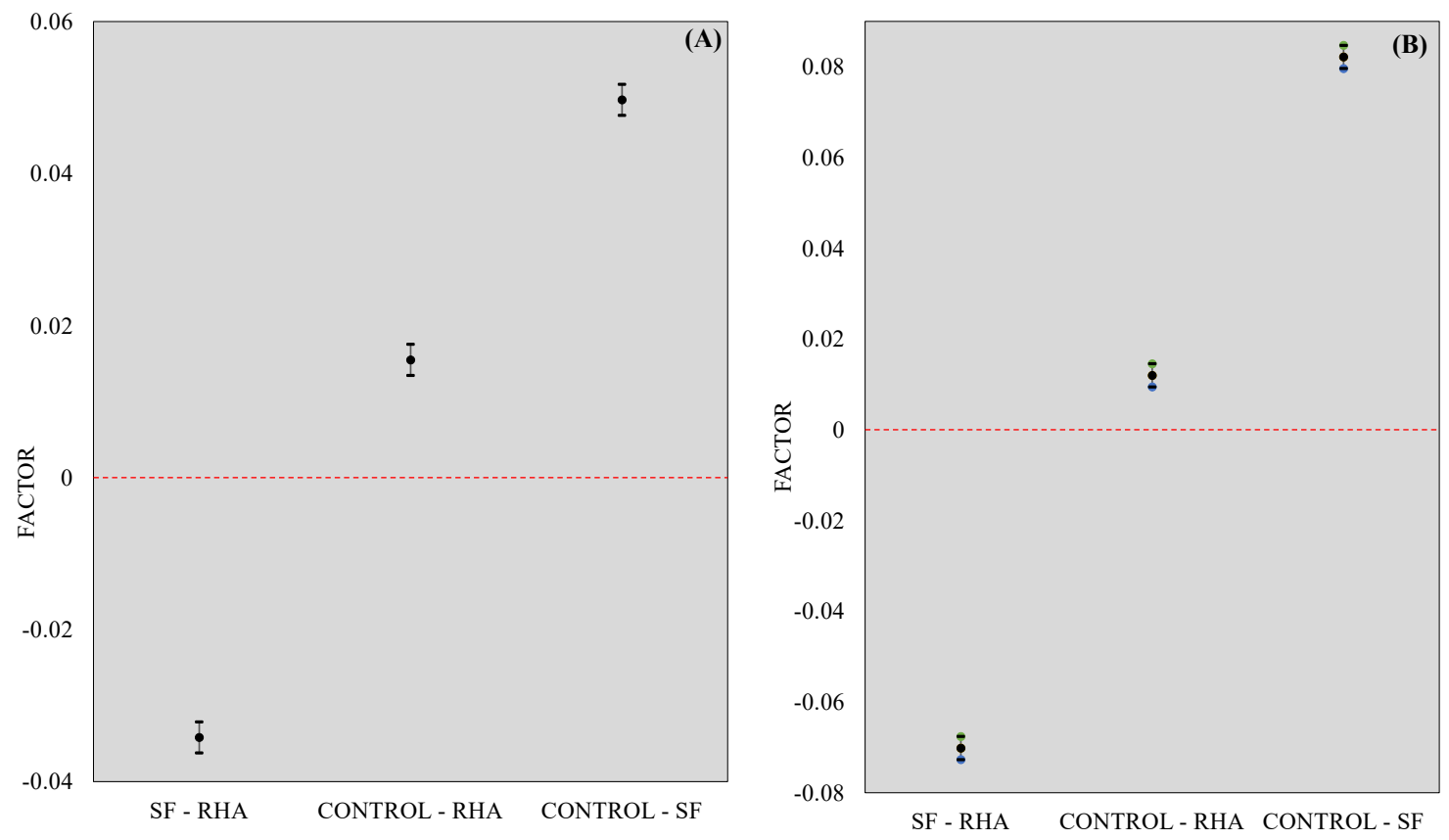

Figure 5. Comparative analysis of the averages, Tukey's test, for 14 (A) and 28 (B) days of exposure among the series studied, for a significance level of $5 \%$.

Although the RHA is classified as material with high pozzolanic reactivity, as demonstrated in materials section through the modified Chapelle's test method. Interestingly, RHA indicates reactivity like SF; however, its behaviour was far different in the mortar bars exposed to ASR development. The particle morphology, chemical composition and particle size distribution showed the main differences between the two SCMs; which may explain the different behaviour measured. AMBT has been criticized in several documents [2], [33]-[35] since it can give "false positives" and "false negatives" answers due to the overly aggressive exposure conditions of the test. Finally, further concrete prism tests should be developed for a better characterization of the RHA in mitigate the ASR. Yet, this was possible to 
be done in the present study once CPT normally takes 2 years of development. Which was a limiting factor in this research.

\subsection{X-ray Diffraction (XRD)}

The main XRD peaks evaluated to identify the influence of the SF and RHA in the mortar bars exposed to ASR development are presented in Figure 6 (100\% of intensity of the mineral Sanidine) and Figure 7 (100\% of intensity of portlandite). It worth noting to mention that Sanidine $\left(\mathrm{KAlSi}_{3} \mathrm{O}_{8}\right)$ is a mineral from the reactive aggregate used, in which have trend to be released and "consumed" along the development of ASR [36]. Therefore, variations on the main intensity peak of this material may indicate the occurrence of ASR in the mortar systems [37]. Clearly, the main peak of Sanidine was affected by the development of the reaction, moreover, the use of SF and RHA slowed down the mineral consumption indicating, indeed, that the reaction was mitigated.

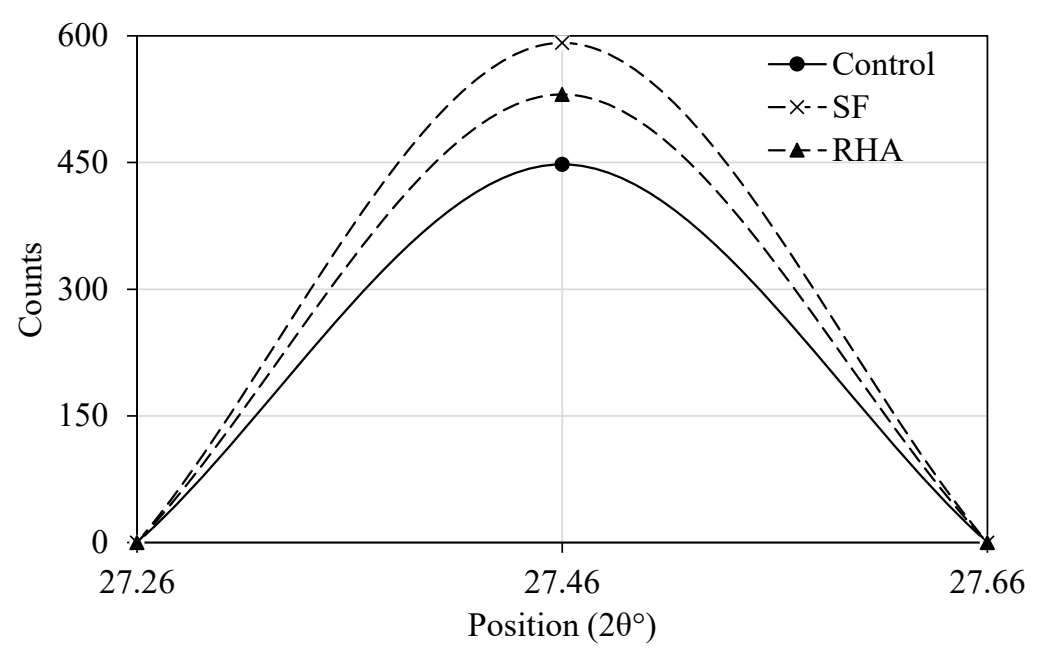

Figure 6. Peak of sanidine.

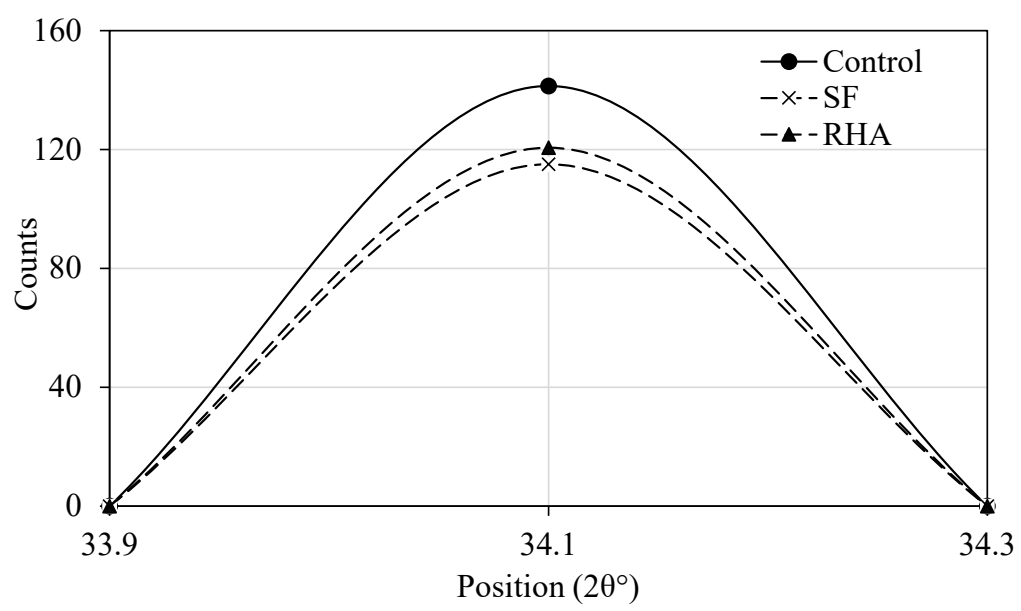

Figure 7. Peak of portlandite.

During the alkali-silica reaction, an electrical double layer of cations (sodium, potassium and/or calcium) develops at the silica surface to offset its negative charge. Later the interaction between both phases (amorphous silica and alkali layers) will initially form a colloidal suspension, then the aggregate will precipitate as ASR gel, depending on the availability of solvent, type of pore solution and its concentration, pore structure, and the conditions to which it is exposed [38]. It has been found that the formation of the outer layer of cations starts hindering the silica uptake over 
time. However, the diffusion of alkaline ions is barely affected, and thus the chemical reaction continues, especially within the aggregate particles. Moreover, different features (viscosity, mechanical properties, chemical composition, etc.) of the reaction products are found at different locations, i.e. alkali-silica gel within the aggregates and lime-alkalisilica gel in the surrounding cement paste [39]-[41].

As the reaction progresses, calcium ions diffuse into the silica particle as well, such that a cation exchange between $\mathrm{Ca}^{2+}$ and alkaline ions begins, releasing the $\mathrm{Na}^{+}$and $\mathrm{K}^{+}$to continue reacting with silica particles. The alkali-silica composition is significantly bulkier than the lime-alkali-silica compositions. As a result, the cracking caused by the ASR is initiated within the aggregates [41], [42].

Overall, cement is the main source of alkalis and portlandite $(\mathrm{CH})$ within the concrete. Thus, it is convenient to use binder materials capable to reduce the final amounts of at least one of these compounds, which is the case of the SF and RHA, both highly reactive SCMs. Moreover, the main peak of portlandite $\left(34.1^{\circ} 2 \theta\right)$ analyzed through XRD indicates that, indeed, the pozzolanic reactivity of the SF and RHA affected the $\mathrm{CH}$ content. It worth noting that to evaluate the peak of portlandite in samples of SF and RHA, the total count of CH was "normalized" (divided by 0.9) to compare directly to Control group. The data normalization excludes alterations in the portlandite peak due to the simple replacement of the cement and only reactions consuming $\mathrm{Ca}(\mathrm{OH})_{2}$ are being evaluated, enhancing that the SCMs, indeed consumed the $\mathrm{CH}$, changing ASR kinetics.

Samples containing SCMs showed smaller portlandite peak, that indicates pozzolanic activity. Differences between total counts were close to $20 \%$ for control sample compared to SCMs samples. Medeiros et al. [43] reported similar results for concretes with Cement Portland and metakaolin and/or silica fume compared with control group (reference). The pozzolanic reaction of the SCMs improved the microstructure of the mortar bars and contributed to the reduction of porosity and permeability. This occurs due to the action of several mechanisms that contributes to the damage limit by ASR [3], [8]-[10], [44].

However, even if XRD results indicate the consume of portlandite due to pozzolanic reactivity, there are several factors regarding the characteristics of the materials that tend to influence the results of the samples expansion, besides the accelerated test itself. Different techniques are needed to provide a more conclusive evaluation.

\subsection{Thermogravimetric Analysis (TGA)}

Qualification and semi-quantification of hydration products through XRD analysis enhance the quality in identify those products formed during ASR; however, to quantify more precisely is necessary to adopted supplementary tests. In this case, the TG/DTG curves of the mortar's samples cured for 32 days. All test specimens present a significant mass reduction at the temperature around $105^{\circ} \mathrm{C}, 420^{\circ} \mathrm{C}$ and $660^{\circ} \mathrm{C}$. It is acknowledged that heating hardened cement paste samples through room temperature to $1000^{\circ} \mathrm{C}$ leads to loss of physically bound water, breakdown of $\mathrm{Ca}(\mathrm{OH})_{2}$ and $\mathrm{CaCO}_{3}$, respectively. The first broad peak between 50 and $200{ }^{\circ} \mathrm{C}$ in the DTG curve corresponds to the dehydration of C-S-H. Between $400-500^{\circ} \mathrm{C}$, the intense peak seen in most of the samples corresponds to the decomposition of calcium hydroxide $(\mathrm{CH})$. The temperature range of $600-800^{\circ} \mathrm{C}$ is considered as decarbonation or losses of carbon dioxide from samples. The amount of portlandite in relation to the loss of mass in the control sample was $4.32 \%$ (Figure 8). The determination of portlandite content $\left(\mathrm{Ca}(\mathrm{OH})_{2}\right)$ consumed in the hydration of samples is indicated in Equation 1:

$$
\mathrm{Ca}(\mathrm{OH})_{2}(\%)=\frac{M M_{\mathrm{Ca}(\mathrm{OH})_{2}}}{\mathrm{MM}_{\mathrm{H}_{2} \mathrm{O}}} \times \mathrm{H}_{2} \mathrm{O}=4.11 \times \mathrm{H}_{2} \mathrm{O}
$$

Where $M M_{\mathrm{Ca}(\mathrm{OH})_{2}}$ is the molecular mass of portlandite; $\mathrm{MM}_{\mathrm{H}_{2} \mathrm{O}}$ is the molecular mass of water and $\mathrm{H}_{2} \mathrm{O}$ is loss of mass, in percentage obtained in test TGA.

Samples containing SCMs presented significantly lower portlandite amount (Figure 8A, 8B and 8C), which is mainly due to the pozzolanic reaction occurred between SCMs and portlandite during the cement hydration [17]. Figure $8 \mathrm{D}$ display the correlation between the expansion amplitudes and portlandite content measured through TGA. Abbas et al. [10] and Kandasamy and Shehata [45] obtained similar results for different supplementary cementitious materials (fly ash, rice husk ash and blast furnace slag) to mitigate ASR. Both studies reported a decrease in the amount of $\mathrm{Ca}(\mathrm{OH})_{2}$ while the expansion due to ASR was reduced. 

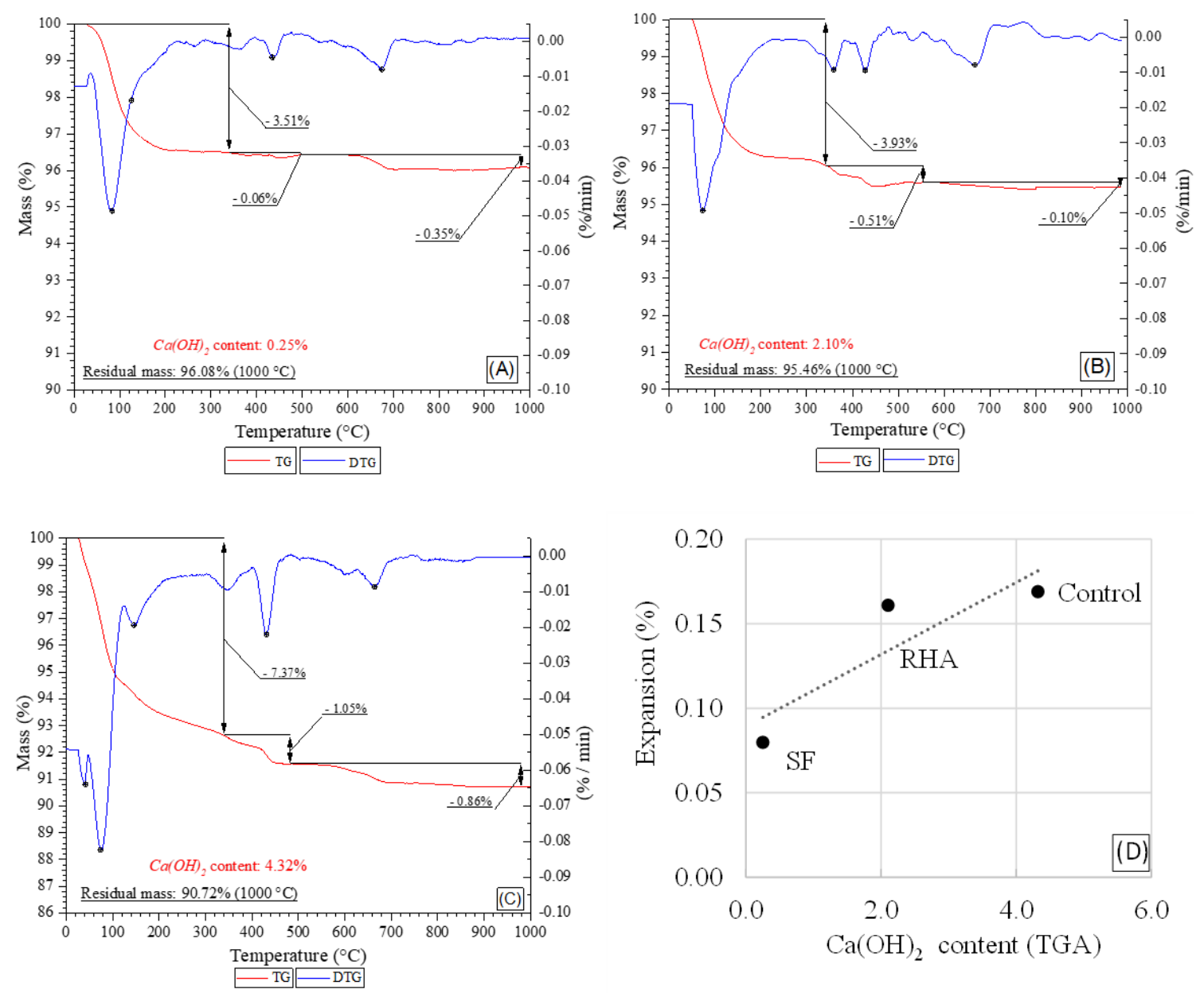

Figure 8. TGA and DTG (A) mortar with SF (B) mortar with RHA (C) Control mortar (D) Correlation between expansion (\%) and portlandite content (\%) (TGA).

The reactivity of the material, the average size of the particles and the amount or replacement are important characteristics that influence the development of the pozzolanic reaction. Although rice husk ash had high reactivity and an improvement in the performance of the mortar compared with the control series, the diffractogram (Figure 3) shows that the microstructure of RHA presented peaks of cristobalite, indicating lower reactivity than silica fume. Hoppe et al. [17] show in their results that the amount of amorphous silica of rice husk ash is an important aspect in the development of pozzolanic activity. Besides, cristobalite is a reactive mineral, potentially alkaline in terms of alkaliaggregate reaction [34], which could have affected the performance of the rice husk ash for mitigating ASR.

The optimized grinding of the material improves the pozzolanic characteristics increasing the specific surface area of grains [16]. According to De Souza et al. [13], impurities as inorganic compounds present in rice husk do not significantly modify the pozzolanic reaction. However, the particles must have a smaller size (micron or submicron). In the same context, Ahsan and Hossain [18] and Thanh et al. [46] showed that finer RHA particles are more efficient to mitigate ASR than the coarser ones. It is well known that smaller particles can quickly react due to the higher surface area that has an important influence of hydration process and on the kinetics of ASR. Coarser RHA particles reduce the packing density of the mixture, leading to a slightly more porous and permeable matrix with an easier percolation of alkaline ions.

PSD of materials showed that the particles of silica fume were 65.75 (D50) times smaller than RHA, and 52 times smaller than grains of Cement Portland. Besides, silica fume presented a higher amount of $\mathrm{SiO}_{2}$ and reactivity, which is significantly influenced by PSD and specific surface area [16], [17], [30]. This indicates that the silica fume was able to significantly modify the microstructure of mortars due to its morphology, chemical composition and reactivity. It is important to consider the short-term evaluation (32 days) and the accelerated test of mortar bars. The particle size 
distribution and the packing density of the mortar presented more influence in the development of ASR than the pozzolanic reactivity by itself, as shown in results of XRD and TGA. The consumption of portlandite was higher for both SCMs compared to the control sample. However, results for induced expansion were significantly different, which may indicate that the physical properties of the silica fume are responsible for controlling the kinetics of ASR for the short-term evaluation used.

\subsection{Mercury Intrusion Porosimetry (MIP)}

Supplementary cementing material may contribute for the reduction of porosity and permeability of mortars, performing by physical effect (better refinement of voids, filling and points of heterogeneous nucleation in cement grains) and chemical effect (pozzolanic reactions). ASR demands water to start and continue the reaction. Thus, the porosity reduction contributes to reduction of expansion due to important points such as: diffusion of external alkalis, decrease of ASR propagation and water absorption by ASR-gel.

The objective of test of mercury intrusion porosimetry was evaluate two important aspects in mortars with SCMs. First, if the pore refinement occurs due to the partial substitution of cement by additions. Second, if the development of ARS may increase this property once crack might be formed along with higher expansion levels.

Samples with SCMs as part of the composition of the binder presented lower total porosity (Figure 9). SF mortar bars showed the best pore refinement according to porosity and pores distribution; moreover, lower coefficient of permeability (Figure 9).

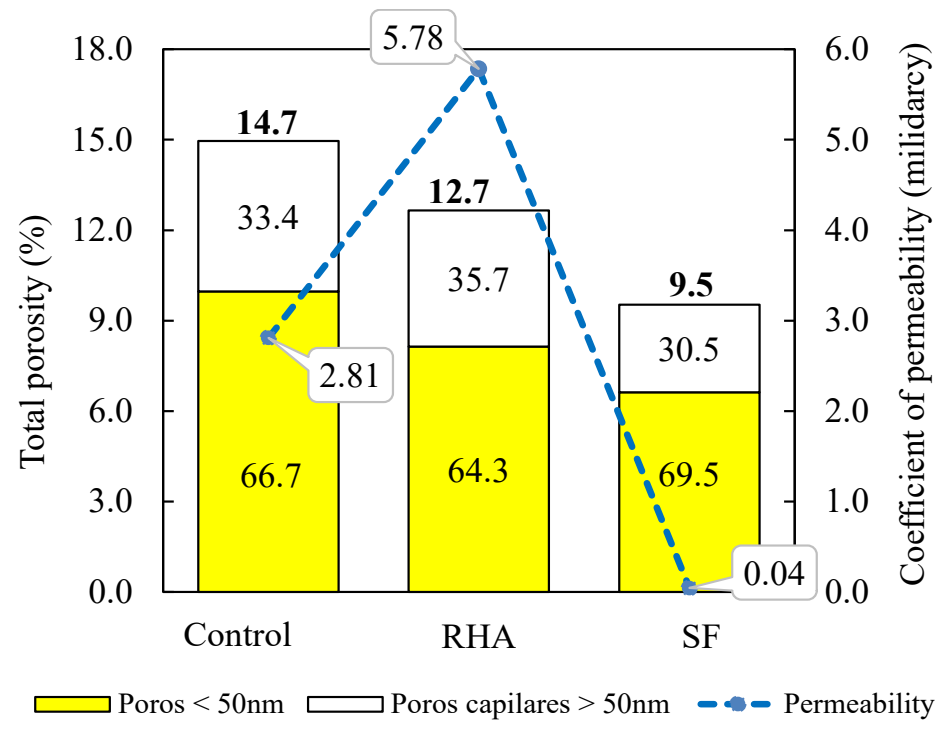

Figure 9. Porosity e permeability of mortars.

Results obtained for silica fume corroborate the results from other tests, showing a lower coefficient of permeability, lower total porosity, and lower expansion of mortar bars (AMBT). This result is consistent with Moser et al. [47], which presented that the use of supplementary cementitious materials in concrete exposed to occurrence of ASR shows lower permeability, contributing to mitigate the reaction and reduce the expansion of samples.

RHA mixtures had permeability coefficient of $5.78 \mathrm{mD}$, higher than $\mathrm{SF}$ and control, despite the lower porosity (in 2\%) compared to control sample. Only because of physical aspects, rice husk ash was not able to increase the packing density. However, due to its high reactivity as SCM, that was pointed out by Chappell's modified method, the secondary products formed with the pozzolanic reaction contributes to filling some voids and in the interparticle space, which explains this small improvement in porosity. Considering the reactivity and formation of the particle of C-S- $\mathrm{H}_{\text {pozzolanic }}$, rice husk ash was not able to totally access the thinner voids and to reduce the permeability of mortar bars. The distribution of the pore diameters demonstrated that $66.7 \%$ of the control samples pores were smaller than $50 \mathrm{~nm}$ (micropores). Mortar with silica fume and rice hunk ash presented $69.5 \%$ and $64.3 \%$ of pores, respectively. 


\subsection{SEM/EDX}

Figure 10 displays the hydrated compounds, such as C-S-H, found in all samples. It is clear that mortar bars containing RHA and SF have higher amounts of $\mathrm{SiO}_{2}$ and $\mathrm{CaO}$ than in control samples (Table 3), which may indicate pozzolanic activity and higher formation of C-S-H. Shafaatian et al. [48] demonstrated that the ratio $\mathrm{CaO} / \mathrm{SiO}_{2}$ of the hydrated material is a good parameter to indicate the mitigative potential for ASR development. Due to the pozzolanic reaction, the $\mathrm{C}-\mathrm{S}-\mathrm{H}_{\text {pozzolanic }}$ has a small amount of $\mathrm{Ca}$ and, therefore, generates a ratio $\mathrm{CaO} / \mathrm{SiO}_{2}$ inferior to the $\mathrm{C}-\mathrm{S}-\mathrm{H}$ formed by hydrated cement without SCMs [10], [44], [49]. The absorption of alkalis by C-S-H changes due to its surface charge, and this depends on the $\mathrm{CaO} / \mathrm{SiO}_{2}$. At low ratios of $\mathrm{CaO} / \mathrm{SiO}_{2}$, the surface charge is negative and the $\mathrm{C}-\mathrm{S}-\mathrm{H}$ pozzolanic formed tends to bond alkalis [9].
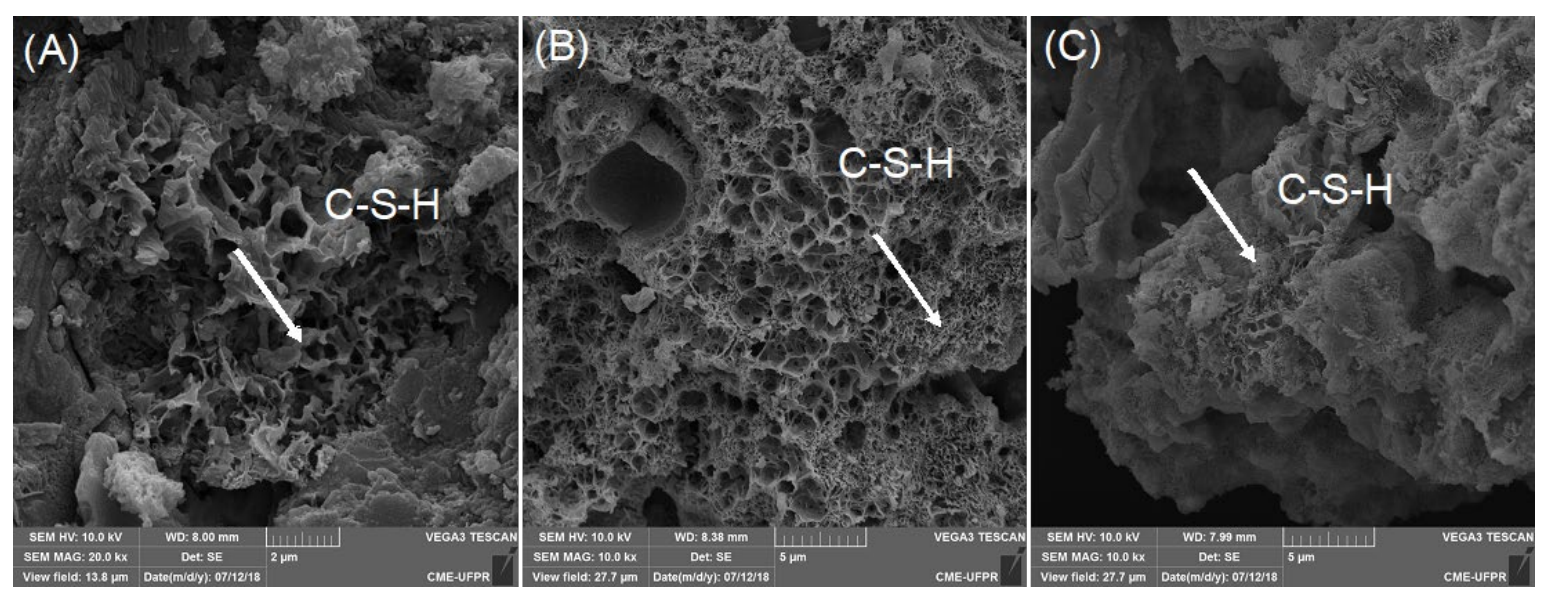

Figure 10. SEM of C-S-H (A) SF (B) RHA (C) Control.

Table 3 shows results from the analysis of EDX of mortars, based on the three points indicated in Figure 10, representing the analysis points.

Table 3. EDX of samples.

\begin{tabular}{|c|c|c|c|c|c|c|c|c|c|}
\hline \multirow{2}{*}{ Sample } & \multicolumn{8}{|c|}{ Mass present } & \multirow{2}{*}{$\frac{\text { Ratio of mass present }}{\mathrm{CaO} / \mathrm{SiO}_{2}}$} \\
\hline & $\mathrm{SiO}_{2}$ & $\mathrm{CaO}$ & $\mathrm{Al}_{2} \mathrm{O}_{3}$ & $\mathrm{Na}_{2} \mathrm{O}$ & $\mathrm{K}_{2} \mathrm{O}$ & $\mathrm{Na}_{2} \mathrm{O}_{\text {eq }}$ & MgO & $\mathrm{Fe}_{2} \mathrm{O}_{3}$ & \\
\hline $\mathrm{SF}$ & 33.16 & 49.53 & 3.21 & 0.00 & 1.69 & 1.11 & 1.99 & 11.72 & 1.49 \\
\hline RHA & 50.01 & 42.54 & 6.42 & 6.60 & 1.69 & 7.71 & 0.00 & 0.00 & 0.85 \\
\hline Control & 18.83 & 51.77 & 5.10 & 3.64 & 0.00 & 3.64 & 0.00 & 3.57 & 2.75 \\
\hline
\end{tabular}

The smaller $\mathrm{CaO} / \mathrm{SiO}_{2}$ ratios were found in samples with SCMs (Table 3) and similar results were found on [10], [44], [49]. Samples containing RHA, although demonstrating smaller ratio $\mathrm{CaO} / \mathrm{SiO}_{2}$ than other samples, the amount of $\mathrm{Na}_{2} \mathrm{O}_{\text {eq }}$ was higher (EDX analysis of C-S-H). Indicating that the smaller ratio of $\mathrm{CaO} / \mathrm{SiO}_{2}$ in C-S-H does not mean that is the best result regarding expansion. However, a small proportion contributes for the positive effect of the pozzolanic SCM. Besides, an analysis of the pore solution is necessary to understand the effects of alkalis present in the cement matrix mixed with different SCMs.

ASR is like the pozzolanic reaction [9]. The difference between both is in the time scale that ASR and pozzolanic reaction occur and regarding the pozzolanic reaction, there is no expansion due to its development mechanisms. The fineness of the SCM used provides a better distribution of C-S-H in the microstructure of the hydrated matrix. This does not happen in ASR, which the reactive silica is placed in discreet points generating a concentration of internal tension. Thus, the physical aspects supplementary cementitious materials are extremely important for their good performance in aspects regarding the alkali-aggregate reaction. In addition, the AMBT test contributes negatively to the pozzolanic reaction. This suggests that the classification of a material is performed using various techniques. 


\section{CONCLUSIONS}

The main objective of this research was to evaluate the influence of the RHA to suppress ASR in mortar bar specimens comparing its behaviour with well-known SCM (silica fume) which has distinguished performance against ASR. The main findings of the current research are presented hereafter:

- Mortar bars made of silica fume demonstrated the best results, showing considerable reduction in damages and decelerating ASR kinetics. The use of SF significantly decreases the permeability and porosity of the mortar and reducing the diffusion of external alkali ions;

- Evaluation of XRD showed that mortars containing SCMs were able to retard the consumption of sanidine, that indicates a lower rate of ASR kinetics. The effect of a release of alkalis and other components (e.g. $\mathrm{SiO}_{2}$ and $\mathrm{Al}_{2} \mathrm{O}_{3}$ ) on aggregates for the porous solution in the development of the reaction is still unknown. Further study is needed to evaluate how each type of reactive aggregate influences in ASR, depending upon the used materials and exposition environment.

- Although the rice husk ash presented high pozzolanic reactivity, its use was not able to reach the same efficiency to suppress ASR as silica fume. The physical properties of the SCM were crucial to on its performance according to the test conditions. Besides the process of controlled burning of ashes, an efficient grinding is required. In this study was used the particle size distribution, that is like the cement. It is also suggested that the test may be carried out in concrete, because AMBT may have inhibited a part of the performance of rice husk ash, due to its accelerated conditions.

- The ratio $\mathrm{CaO} / \mathrm{SiO}_{2}$ of the C-S-H $\mathrm{H}_{\text {pozzolanic }}$ found in mortar containing $\mathrm{SCMs}$ was smaller than the ratio C-S-H $\mathrm{CaO} / \mathrm{SiO}_{2}$ of the control mortar. This is an aspect related with the presence of the pozzolan reaction and the density of the hydration products, positively contributing to the reduction of expansion caused by ASR. However, the alkaline bond is not the only mechanism acting to contribute for the mitigation of ASR by SCMs. AMBT test can occult this aspect depending on the material used.

\section{ACKNOWLEDGEMENTS}

The authors would like to acknowledge the Post-graduation in Civil Construction Engineering (PPGECC) of Federal University of Parana and the financial support provided by CAPES (Coordination for the Improvement of Higher Education Personnel).

\section{REFERENCES}

[1] M. Limbachiya, S. C. Bostanci, and H. Kew, "Suitability of BS EN 197-1 CEM II and CEM V cement for production of low carbon concrete," Constr. Build. Mater., vol. 71, pp. 397-405, Nov 2014, http://dx.doi.org/10.1016/j.conbuildmat.2014.08.061.

[2] B. Fournier and M. A. Bérubé, "Alkali-aggregate reaction in concrete: a review of basic concepts and engineering implications," Can. J. Civ. Eng., vol. 27, no. 2, pp. 167-191, Apr 2000, http://dx.doi.org/10.1139/199-072.

[3] N. P. Hasparyk, P. J. M. Monteiro, and H. Carasek, "Effect of silica fume and rice husk ash on alkali-silica reaction," ACI Mater. J., vol. 97, no. 4, pp. 486-492, Jan 2001.

[4] J. M. Ponce and O. R. Batic, "Different manifestations of the alkali-silica reaction in concrete according to the reaction kinetics of the reactive aggregate," Cement Concr. Res., vol. 36, no. 6, pp. 1148-1156, 2006, http://dx.doi.org/10.1016/j.cemconres.2005.12.022.

[5] P. Helene, M. Carvalho, and J. Pacheco, "Engineering field tests for alkali-aggregate reaction," Struct. Concr., vol. 18, no. 2, pp. 349-355, Oct 2017, http://dx.doi.org/10.1002/suco.201600090.

[6] J. Lindgård, Ö. Andiç-Çakir, I. Fernandes, T. F. Rønning, and M. D. A. Thomas, "Alkali-silica reactions (ASR): Literature review on parameters influencing laboratory performance testing," Cement Concr. Res., vol. 42, no. 2, pp. 223-243, Feb 2012, http://dx.doi.org/10.1016/j.cemconres.2011.10.004.

[7] J. Duchesne and Q. City, "Another look at the reaction mechanisms," Cement Concr. Res., vol. 24, no. 2, pp. $221-230$, 1994.

[8] W. Aquino, D. A. Lange, and J. Olek, "The influence of metakaolin and silica fume on the chemistry of alkali-silica reaction products," Cement Concr. Compos., vol. 23, no. 6, pp. 485-493, Dec 2001, http://dx.doi.org/10.1016/S0958-9465(00)00096-2.

[9] M. Thomas, "The effect of supplementary cementing materials on alkali-silica reaction: a review," Cement Concr. Res., vol. 41, no. 12, pp. 1224-1231, Dec 2011, http://dx.doi.org/10.1016/j.cemconres.2010.11.003.

[10] S. Abbas, S. M. S. Kazmi, and M. J. Munir, "Potential of rice husk ash for mitigating the alkali-silica reaction in mortar bars incorporating reactive aggregates," Constr. Build. Mater., vol. 132, no. 1, pp. 61-70, Feb 2017, http://dx.doi.org/10.1016/j.conbuildmat.2016.11.126.

[11] M. H. Shehata and M. D. A. Thomas, "Use of ternary blends containing silica fume and fly ash to suppress expansion due to alkalisilica reaction in concrete," Cement Concr. Res., vol. 32, no. 3, pp. 341-349, 2002, http://dx.doi.org/10.1016/S0008-8846(01)00680-9 
[12] D. J. Souza, M. H. F. Medeiros, and A. N. D. J. Hoppe Fo., "Evaluation of external sulfate attack $\left(\mathrm{Na}_{2} \mathrm{SO}_{4}\right.$ and $\left.\mathrm{MgSO}_{4}\right)$ : Portland cement mortars containing siliceous supplementary cementitious materials," Rev. IBRACON Estrut. Mater., vol. 13, no. 4, pp. e13403, Sep 2020, http://dx.doi.org/10.1590/s1983-41952020000400003.

[13] M. F. De Souza, P. S. Batista, I. Regiani, J. B. L. Liborio, and D. P. F. Souza, "Rice hull-derived silica: applications in Portland cement and mullite whiskers," Mater. Res., vol. 3, no. 2, pp. 25-30, Apr 2000, http://dx.doi.org/10.1590/S1516-14392000000200005.

[14] R. A. Bakar, R. Yahya, and S. N. Gan, "Production of high purity amorphous silica from rice husk," Procedia Chem., vol. 19, pp. 189-195, 2016, http://dx.doi.org/10.1016/j.proche.2016.03.092.

[15] R. Zerbino, G. Giaccio, and G. C. Isaia, "Concrete incorporating rice-husk ash without processing," Constr. Build. Mater., vol. 25, no. 1, pp. 371-378, Jan 2011, http://dx.doi.org/10.1016/j.conbuildmat.2010.06.016.

[16] J. H. S. Rêgo, A. A. Nepomuceno, E. P. Figueiredo, and N. P. Hasparyk, "Microstructure of cement pastes with residual rice husk ash of low amorphous silica content," Constr. Build. Mater., vol. 80, pp. 56-68, Apr 2015, http://dx.doi.org/10.1016/j.conbuildmat.2014.12.059.

[17] J. Hoppe Fo., M. R. Garcez, E. O. Garcez, L. C. P. Silva Fo., and G. C. Isaia, "Evaluation of residual rice husk ash reactivity," $J$. Aust. Ceram. Soc, vol. 53, no. 2, pp. 917-924, 2017, http://dx.doi.org/10.1007/s41779-017-0106-y.

[18] M. B. Ahsan and Z. Hossain, "Supplemental use of rice husk ash (RHA) as a cementitious material in concrete industry," Constr. Build. Mater., vol. 178, pp. 1-9, Jul 2018, http://dx.doi.org/10.1016/j.conbuildmat.2018.05.101.

[19] V. P. Della, I. Kühn, and D. Hotza, "Rice husk ash as an alternate source for active silica production," Mater. Lett., vol. 57, no. 4, pp. 818-821, Dec 2002, http://dx.doi.org/10.1016/S0167-577X(02)00879-0.

[20] S. K. Antiohos, V. G. Papadakis, and S. Tsimas, "Rice husk ash (RHA) effectiveness in cement and concrete as a function of reactive silica and fineness," Cement Concr. Res., vol. 61-62, pp. 20-27, 2014, http://dx.doi.org/10.1016/j.cemconres.2014.04.001.

[21] B. K. H. Obla, "Specifying fly ash for use in concrete," Concr. Focus, vol. 7, no. 1, pp. 60-66, 2008.

[22] L. Valduga, "Influência das condições de ensaio da ASTM C 1260 na verificação da reação álcali-agregado," Ph.D. dissertation, Prog. Pós-grad. Eng. Civ., Univ. Fed. Rio Grande do Sul, Porto Alegre, 2007.

[23] American Society for Testing and Materials, Standard Descriptive Nomenclature for Constituents of Concrete, ASTM C294-12, 2017.

[24] D. Constantiner and S. Diamond, "Alkali release from feldspars into pore solutions," Cement Concr. Res., vol. 33, no. 4, pp. 549554, Apr 2003, http://dx.doi.org/10.1016/S0008-8846(02)01001-3.

[25] F. Locati, S. Marfil, E. Baldo, and P. Maiza, "Na $\mathrm{Na}_{2} \mathrm{O} \mathrm{K}_{2} \mathrm{O}, \mathrm{SiO}_{2}$ and $\mathrm{Al}_{2} \mathrm{O}_{3}$ release from potassic and calcic - sodic feldspars into alkaline solutions," Cement Concr. Res., vol. 40, no. 8, pp. 1189-1196, Aug 2010, http://dx.doi.org/10.1016/j.cemconres.2010.04.005.

[26] American Society for Testing and Materials, Standard Specification for Portland Cement, ASTM C150/C150M, 2019.

[27] A. Muthadhi and S. Kothandaraman, "Experimental investigations of performance characteristics of rice husk ash-blended concrete," J. Mater. Civ. Eng., vol. 25, no. 8, pp. 1115-1118, 2013, http://dx.doi.org/10.1061/(ASCE)MT.1943-5533.0000656.

[28] American Society for Testing and Materials, Standard Test Method for Potential Alkali Reactivity of Aggregates (Mortar-Bar Method), ASTM C1260-14, 2014.

[29] American Society for Testing and Materials, Standard Specification for Coal Fly Ash and Raw or Calcined Natural Pozzolan for Use in Concrete, ASTM C618, 2019.

[30] J. Hoppe Fo., M. R. Garcez, M. H. F. Medeiros, L. C. P. Silva Fo., and G. C. Isaia, "Reactivity assessment of residual rice-husk ashes," J. Mater. Civ. Eng., vol. 29, no. 6, pp. 1-7, 2017, http://dx.doi.org/10.1061/(ASCE)MT.1943-5533.0001820.

[31] Associação Brasileira de Normas Técnicas, Materiais Pozolânicos - Determinação do Teor de Hidróxido de Cálcio Fixado - Método Chapelle Modificado, NBR 1589, 2010.

[32] American Society for Testing and Materials, Standard Test Method for Determining the Potential Alkali-Silica Reactivity of Combinations of Cementitious Materials and Aggregate (Accelerated Mortar-Bar Method), ASTM C1567-13, 2013.

[33] F. Golmakani and R. D. Hooton, "Comparison of laboratory performance tests used to assess alkali-silica reactivity," in Proc. Can. Soc. Civ. Eng. Conf., vol. 2, 2016, pp. 1-7.

[34] R. A. Deschenes Jr. and W. Micah Hale, "Alkali-silica reaction in concrete with previously inert aggregates," J. Perform. Constr. Facil., vol. 31, no. 2, 04016084, Apr 2017, http://dx.doi.org/10.1061/(ASCE)CF.1943-5509.0000946.

[35] M. Thomas, B. Fournier, K. Folliard, J. Ideker, and M. Shehata, "Test methods for evaluating preventive measures for controlling expansion due to alkali-silica reaction in concrete," Cement Concr. Res., vol. 36, no. 10, pp. 1842-1856, Oct 2006, http://dx.doi.org/10.1016/j.cemconres.2006.01.014.

[36] Laboratório Nacional de Engenharia Civil, Betões Metodologia para Prevenir Reacções Expansivas Internas, LNEC E $461,2007$.

[37] M. A. T. M. Broekmans, "Deleterious reactions of aggregate with alkalis in concrete," Rev. Mineral. Geochem., vol. 74, no. 1, pp. 279-364, 2012, http://dx.doi.org/10.2138/rmg.2012.74.7. 
[38] M. Prezzi, P. J. M. Monteiro, and G. Sposito, "The alkali-silica reaction, part I: use of the double-layer theory to explain the behaviour of reaction-product gels," ACI Mater. J., vol. 94, pp. 10-17, 1997, http://dx.doi.org/10.14359/280.

[39] S. Chatterji, "Chemistry of alkali-silica reaction and testing of aggregates," Cement Concr. Compos., vol. 27, no. 7-8, pp. 788-795, 2005, http://dx.doi.org/10.1016/j.cemconcomp.2005.03.005.

[40] S. Chatterji, A. D. Jensen, N. Thaulow, and P. Christensen, "Studies of alkali-silica reaction. Part 3. mechanisms by which naci and $\mathrm{Ca}(\mathrm{OH})_{2}$ affect the reaction," Cement Concr. Res., vol. 16, no. 2, pp. 246-254, Mar 1986, http://dx.doi.org/10.1016/00088846(86)90141-9.

[41] T. Ichikawa and M. Miura, "Modified model of alkali-silica reaction," Cement Concr. Res., vol. 37, no. 9, pp. 1291-1297, Sep 2007, http://dx.doi.org/10.1016/j.cemconres.2007.06.008.

[42] H. Wang and J. E. Gillott, "Mechanism of alkali-silica reaction and the significance of calcium hydroxide," Cement Concr. Res., vol. 21, no. 4, pp. 647-654, Jul 1991, http://dx.doi.org/10.1016/0008-8846(91)90115-X.

[43] M. H. F. Medeiros, J. W. Raisdorfer, and J. Hoppe Fo., "Influência da sílica ativa e do metacaulim na velocidade de carbonatação do concreto: relação com resistência, absorção e relação a/c," Ambient. Constr., vol. 17, no. 4, pp. 125-139, 2017 , http://dx.doi.org/10.1590/s1678-86212017000400189.

[44] J. H. S. Rêgo, A. A. Nepomuceno, E. P. Figueiredo, N. P. Hasparyk, and L. D. Borges, "Effect of particle size of residual rice-husk ash in consumption of $\mathrm{Ca}(\mathrm{OH})_{2}, "$ J. Mater. Civ. Eng., vol. 27, no. 6, pp. 1-9, Jun 2015, http://dx.doi.org/10.1061/(ASCE)MT.19435533.0001136.

[45] S. Kandasamy and M. H. Shehata, "The capacity of ternary blends containing slag and high-calcium fly ash to mitigate alkali silica reaction," Cement Concr. Compos., vol. 49, pp. 92-99, May 2014, http://dx.doi.org/10.1016/j.cemconcomp.2013.12.008.

[46] H. T. Le, K. Siewert, and H.-M. Ludwig, "Alkali silica reaction in mortar formulated from self-compacting high-performance concrete containing rice husk ash," Constr. Build. Mater., vol. 88, pp. 10-19, Jul 2015, http://dx.doi.org/10.1016/j.conbuildmat.2015.04.005.

[47] R. D. Moser, A. R. Jayapalan, V. Y. Garas, and K. E. Kurtis, "Assessment of binary and ternary blends of metakaolin and Class C fly ash for alkali-silica reaction mitigation in concrete," Cement Concr. Res., vol. 40, no. 12, pp. 1664-1672, Dec 2010, http://dx.doi.org/10.1016/j.cemconres.2010.08.006.

[48] S. M. H. Shafaatian, A. Akhavan, H. Maraghechi, and F. Rajabipour, "How does fly ash mitigate alkali-silica reaction (ASR) in accelerated mortar bar test (ASTM C1567)," Cement Concr. Compos., vol. 37, no. 1, pp. 143-153, Mar 2013, http://dx.doi.org/10.1016/j.cemconcomp.2012.11.004.

[49] M. H. Shehata, M. D. A. Thomas, and R. F. Bleszynski, "The effects of fly ash composition on the chemistry of pore solution in hydrated cement pastes," Cement Concr. Res., vol. 29, no. 12, pp. 1915-1920, Dec 1999, http://dx.doi.org/10.1016/S00088846(99)00190-8.

Author contributions: CAS, MHFM conceived the presented idea. EAL, CAS developed the written work presented in the paper. DSJ reviewed the English. CAS, EP performed the experimental analysis. All authors discussed the results and contributed to the final manuscript.

Editors: Fernando Soares Fonseca, José Luiz Antunes de Oliveira e Sousa, Guilherme Aris Parsekian. 